\title{
(When) Do Critical Life Events Push People to the Populist Radical Right? Support for the Swiss People's Party Following Relationship Dissolution, Unemployment or a Health Crisis
}

\author{
Marieke Voorpostel ${ }^{*}$, Ursina Kuhn*, and Gian-Andrea Monsch*
}

Abstract: Using the Swiss Household Panel, we examine whether experiencing relationship dissolution, unemployment, or a health crisis increases support for the Swiss People's Party (SVP). Fixed effects models shows this to be the case. Changes in financial resources, attitudes or trust in the government cannot explain this effect. Finally, we test whether increased support for the SVP following these events is more likely among individuals with lower trust and income levels and with views similar of those of the SVP. We find that individuals with traditional gender values are more likely to support the SVP after separation.

Keywords: critical life events, populist radical right, party preference, panel data

(Quand) les événements critiques de la vie poussent-ils les gens vers la droite populiste ? Soutien à I'UDC à la suite de la séparation, du chômage ou d'une crise de santé

Résumé: À l'aide du Panel suisse de ménages, nous examinons si une séparation, le chômage ou une crise de santé augmentent le soutien au Parti union démocratique du centre (UDC). Les modèles à effets fixes montrent que c'est le cas. Les changements dans les ressources financières, les attitudes ou la confiance dans le gouvernement ne peuvent expliquer cet effet. Enfin, nous vérifions si un soutien accru à l'UDC suivant un évènement est plus probable chez les personnes ayant des niveaux de confiance et de revenu plus faibles et des opinions similaires à celles de l'UDC. Nous constatons que les personnes ayant des valeurs traditionnelles de genre sont plus susceptibles de soutenir l'UDC après une séparation.

Mots-clés: événements de vie critiques, droite populiste, préférence partisane, données du panel

(Wann) drängen kritische Lebensereignisse Menschen zu den populistischen Parteien? Unterstützung der SVP nach Trennung, Arbeitslosigkeit oder Gesundheitskrise

Zusammenfassung: Mit dem Schweizer Haushalt-Panel untersuchen wir, ob eine Trennung, Arbeitslosigkeit oder eine Gesundheitskrise die Unterstützung für die Schweizerische Volkspartei (SVP) erhöht. Fixed Effects Modelle zeigen, dass dies der Fall ist. Veränderungen der finanziellen Ressourcen, der Einstellungen oder des Vertrauens in die Regierung können diesen Effekt nicht erklären. Schliesslich testen wir, ob eine verstärkte Unterstützung für die SVP bei Personen mit geringerem Vertrauens- und Einkommensniveau und mit ähnlichen Ansichten wie die SVP wahrscheinlicher ist. Wir stellen fest, dass Personen mit traditionellen Geschlechterwerten die SVP nach der Trennung eher unterstützen.

Schlüsselwörter: kritische Lebensereignisse, Rechtspopulismus, Parteipräferenz, Paneldaten

University of Lausanne, Swiss Centre of Expertise in the Social Sciences (FORS), CH-1015 Lausanne, marieke.voorpostel@fors.unil.ch, ursina.kuhn@fors.unil.ch, gian-andrea.monsch@ fors.unil.ch 
Critical life events, such as a relationship dissolution, loss of a job or a health crisis, have profound consequences in many life domains. They are often accompanied by a loss in resources and increased stress levels and may change future prospects and expectations. As a result, they may translate into changed views on society and the role of the government, with the potential to affect political party preferences.

Previous research has demonstrated that relationship dissolution affects political party preference in Switzerland. Based on longitudinal data from the Swiss Household Panel, Voorpostel and colleagues (2018) showed that separation increased the likelihood to support the populist right Swiss People's Party (SVP). This finding was contrary to the anticipated shift to the left following separation (Chapman 1985; Fahs 2007; Smith 2007; Wilson and Lusztig 2004); with decreasing financial resources and often increased need for support such as childcare, separation was thought to increase support for left-wing parties. Our study expands on previous work on the association between life events and support for the populist right by assessing multiple life events, namely separation, unemployment and a health crisis.

The literature on voting behaviour provides many explanations for the support of populist right parties (Arzheimer 2011; Bornschier and Kriesi 2012; Oesch 2008). Studies that looked at populist right party support on the individual level have shown that losers of globalisation (economic dimension), individuals with xenophobic and inward looking attitudes (cultural dimension) and citizens with low levels of trust in the political establishment (political dimension) are relatively more likely to vote for the radical populist right. We test whether these arguments explain increased support for the SVP following critical life events. A critical life event may decrease financial security, change life prospects and produce uncertainty, through which it may affect each of these three dimensions. We argue that these changes make individuals more likely to recognize themselves in the discourse of the SVP promoting an exclusionist view on society, as well as a firm stance against immigration and European integration (Bernhard 2017; Betz 1994), and eventually result in increased support for this party. Finally, we examine whether increased support for the SVP following a critical life event may be especially likely among individuals with lower income levels and those who already are close or in line with the views of the SVP prior to the event. 


\section{Theoretical background}

2.1 The Swiss People's Party, populist radical right wing party support and volatility in political party preference

Populist radical right parties have a common ideology based on nativism, authoritarianism and populism (Mudde 2007). The SVP is part of this party family that has gained substantial electoral support over the last decades in Switzerland and in Western democracies in general (Bernard 2017). The SVP has evolved from a conservative agrarian party to a radical right and increasingly authoritarian party (McGann and Kitschelt 2005). The SVP strongly opposes immigration and European integration and advocates traditional gender roles. Although the SVP is the largest party in Switzerland (with a vote share of 26 per cent in 2019) and part of the Swiss federal government, with its populist discourse it presents itself and is perceived as an opposition party rather than as a part of the political establishment.

Explaining support for the populist radical right in general and for the SVP in particular does not differ from explaining support for other parties (Arzheimer 2018 ) and is based on the idea that political preferences are replacing class and religious cleavages (Bornschier and Kriesi 2012,10). This shift from social structure to individual preferences proposes three explanations for support for the populist radical right: an economic, cultural and political explanation.

The economic explanation argues that the so-called "losers of globalisation" who are confronted with wage pressure and competition over welfare benefits are attracted by populist radical right parties who have endorsed a protectionist stance and fight European and other forms of economic integration (Borschnier and Kriesi 2012; McGann and Kitschelt 2005). The empirical evidence shows that typical populist radical right wing voters are predominantly low educated young men belonging to the working or lower middle class or who are unemployed (Arzheimer 2011). Besides economic protectionism, the political agenda of these parties also conveys a shelter for the "homeland culture". This is the cultural explanation for the electoral success of populist radical right parties when they portray immigration and further European integration as a threat to national identity, security and the welfare state (Amengay and Stockemer 2018; Rydgren 2007; Bornschier and Kriesi 2012; Oesch 2008). Xenophobic attitudes, especially anti-immigrant sentiments, have proven to be a crucial explanation of populist radical right voting (Arzheimer 2011). Finally, according to the political explanation put forward to explain the success of the populist radical right, citizens who are dissatisfied with the state of democracy in their country are sensitive to an anti-elite discourse challenging mainstream parties (Kitschelt and McGann 1995; Oesch 2008). These three explanations are related to each other. As Betz (1994) has already argued two decades ago, radical social and economic transformations generate feelings of anxiety, disenchantments and resentment within the most vulnerable segments of society (economic explanation). The 
populist radical right has succeeded in mobilizing these social groups by pointing to the unresponsiveness of the political establishment (political explanation) and by identifying immigrants as scapegoats (cultural explanation).

The cultural explanation has proven to be the most important one for populist radical right voting in Switzerland, but also in other Western European countries (Arzheimer 2011; Lubbers and Coenders 2017). In Switzerland, exclusionist views, such as protection of the national identity against outsiders (Oesch 2008, 349), anti-universalistic cultural preferences (Bornschier and Kriesi 2012,28) or generally negative attitudes towards immigration (Ackermann et al. 2018, 553-554), have been found to be strongly correlated with support for the populist radical right.

Our study focuses on a change in preference for the SVP, which implies that we assess volatility in party preference. As individual preferences have become more central to political party choice, volatility in party preference has increased. Although studies have shown that most voters have stable party preferences (Kuhn 2016; Plutzer 2002; Prior 2010), a significant minority of voters change their party preference over time (Nicolet and Sciarini 2006). This volatility is not random; rather, voters tend to change between parties that are closely aligned (Kuhn 2009; Van der Meer et al. 2015). The literature suggests several drivers of volatility in political party preference. A number of these drivers reflect individual circumstances and attitudes, such as changes in a person's financial situation (Sanders and Brynin 1999), changes in attitudes and values or in salience of these values (Aarts and Thomassen 2008) and decreased trust in political parties and in democracy (Dalton and Weldon 2005; Dassonneville 2012). We argue that these drivers of volatility become salient in the face of critical life events and may lead to changes in political party preferences. The direction in which they change is expected to increase the likelihood of supporting the SVP.

\subsection{Literature review: critical life events and populist radical right voting}

Our study focuses on three critical life events: relationship dissolution, unemployment and serious health problems. A commonality of these events is that they tend to have negative consequences in multiple life domains. They are discrete events that negatively affect health and well-being, increase stress levels and are the events typically included in studies on these outcomes (Luhmann et al. 2012). As such, these events may profoundly change one's views of the world and one's place in it (Janoff-Bulman 1999) and, as a result, have the potential to affect political party preferences. ${ }^{1}$

1 Another negative life event often studied is bereavement. We tested the effects of a household member or a close person's death but did not include bereavement into the analysis because its consequences on various life domains are less direct. We did not find any effect on party preferences. 
While some US studies have demonstrated that a link exists between negative feelings and populist radical right support for entire life trajectories (Cramer 2016; Hochschild 2016), only a few studies have directly linked life events to vote intention for the populist radical right at the individual level. In their study on the link between relationship dissolution and political party preference, Voorpostel and colleagues (2018) showed that this type of critical life event has a small but significant effect on party preference, showing, in particular, an increase in support for the SVP. However, a study based on data from the UK showed no effect of this event on party preference (Kern 2010).

The relationship between the event of unemployment and populist radical right voting has received more research attention. Many studies on the relationship between unemployment and populist radical right voting show that unemployment and job insecurity are associated with increased support for the populist radical right, both in cross-sectional (Corbetta and Colocca 2013) and longitudinal studies (Geishecker and Siedler 2011; Rink et al. 2008). However, some studies have found no relationship (Schmitt-Beck et al. 2006) or only for individuals with high levels of political interest (Kohler 2002). Others have demonstrated that negative work experiences lead to political alienation rather than to right-wing voting (Schraff 2019).

The study of health impediments and political attitudes and behaviour has received little attention. Schur and Adya (2013) showed with US data that people with disabilities tend to favour more government involvement in employment and healthcare but also are more critical of government responsiveness and trustworthiness. It remains to be seen to what extent these findings translate to health crises more generally in the Swiss context.

\subsection{Linking critical life events to increased support for the SVP}

What is it about these life events that could make the populist radical right more attractive to those who experience them? In contemporary society in which responsibility for success or failure is increasingly individualized, fear and insecurity associated with these events may translate into resentment for perceived 'enemies' such as immigrants but also mainstream politics (Salmela and Von Scheve 2017). Betz' (1994; 2005) prominent theory on the emotion of resentment suggests that support for populist right wing parties mainly comes from those who experience insecurity about their identity, work and entire life; fear the loss of social cohesion and traditional social bonds; or experience distrust in politics and democracy. The experience of critical life events with significant negative consequences could be important drivers of such feelings of alienation, insecurity and distrust and be related to the main factors explaining voting for the populist radical right.

With regard to the economic explanation of populist radical right voting, it has been well-established that the three life events in this study all tend to be accompanied by a drop in income, which may lead to financial difficulties (Batavia 
and Beaulaurier 2001; Brand 2015; Schofield et al. 2010; Vaus et al. 2017). One's financial situation may affect political orientations, such as views on the role of the welfare state (Andersen and Curtis 2014).

The cultural explanation for populist radical right voting focuses on attitudes. A number of psychological studies have demonstrated a relationship between life events and changes in attitudes (Bardi et al. 2009). The theoretical approach behind these studies focuses on the role that uncertainty plays and states that unexpected events lead to the need for affirmation of beliefs (Heine et al. 2006). Based on longitudinal data from the US, Randles and colleagues (2017) showed that the experience of events such as bereavement, relationship dissolution or financial difficulties increased a preference for conservative perspectives, as well as made people more polarized in existing beliefs. Hatemi (2013) found that individuals who suffered an economic risk event (e.g., major financial problems, unemployment, divorce or separation) were less supportive of immigration. Individuals who face deteriorating circumstances following critical life events may feel more vulnerable and hence may buy into the SVP's narrative on immigration and social spending.

With regard to attitudes, we also consider views on gender as the SVP advocates traditional gender roles. According to their view, mothers of young children should not be in the labour force and the state should not spend money on childcare, which is seen as a private responsibility. In this sense, it deviates from a number of successful far-right European populist parties that have embraced more progressive values (Duina and Carson 2019). As relationship dissolution, unemployment and serious health problems all likely affect the division of labour in the household, these events may also shift attitudes on gender roles towards the attitudes of the SVP.

Little is known about whether critical life events decrease trust in government, which captures the political explanation for populist radical right support (Billiet and de Witte 1995; Hooghe et al. 2011). All three events are likely to increase contact with and dependence on public authorities and services, which have the potential to affect the trust people place in the government in general.

In sum, the experience of each of these three critical life events may affect financial resources, lower confidence in the government and change citizens' attitudes closer to the positions held by the SVP. While there is some evidence that all three life events decrease political engagement in general (Voorpostel and Coffé 2012; Schraff 2019; Schur and Adya 2013), a switch to the SVP is a theoretically plausible alternative.

\subsection{Our study}

We examine the relationship between critical life events and SVP voting in three steps. First, we check whether such a relationship exists: are individuals who experienced one of the three events more likely to support the SVP after the event? In an effort to explain this relationship, we explore in a second step the extent to which changes 
in the aforementioned explanatory factors of income, attitudes and trust associated with these events explain the relationship between life events and SVP preference. Finally, the same life event may have very different effects on different people; the lack of resources to cope with critical life events, especially for those from lower socio-economic classes, may make experiencing them all the more stressful, fuelling feelings of threat and marginalisation (Bjørklund 2007). This, in turn, may increase support for populist right wing parties particularly among the lower income group. Also, it may not be very likely that individuals who are positioned far away from the radical right electorate in terms of attitudes, would change their views so dramatically following a life event and express a preference for the SVP. More likely, individuals already aligned with the views of the populist radical right may be the most likely to support the SVP following a life event. Additionally, individuals with lower levels of trust prior to the event may be more likely to prefer the populist radical right after. Hence, in a final step we will assess whether the increased support for the SVP is especially likely to occur among individuals with fewer financial resources, individuals with views already closer aligned with the SVP's programme and those with lower levels of trust prior to the event.

\section{Data and method}

\subsection{Data and sample selection}

We use data from the three main SHP samples (which started in 1999, 2004 and 2013) and the supplementary sample for the canton of Vaud that started in $2013 .^{2}$ Because political variables and gender attitudes have not been collected in all survey years, the analysis is restricted to the years 2002-2009, 2011, 2014 and 2017. The selection of the years has impacts on the results. The effect is strongest in the period before 2015, which is the year the SVP reached its best electoral result so far $(29.4 \%$ in the national election) and was again represented with two seats in the federal council. ${ }^{3}$

We do not use survey weights because the standard weights do not correct bias for political variables. Moreover, by excluding foreigners and young individuals (who have no right to vote), we analyse a specific sub-group of the SHP sample. In addition, we selected for each event a treatment group (those who experienced the event during the period of observation) and a control group of individuals who did not experience the event but were at risk of the event occurring.

Regarding the separation variable, the control group refers to partnered individuals who have cohabited (either married or unmarried) for at least two years. The

2 In total, we had 44,026 observations (person-years) from SHP I (or 62\%), 18,818 from SHP II (or 26\%), 44,026 from SHP III (or 10\%) and 1,353 SHP VD (or 2\%).

3 The limited number of events does not allow us to analyse different time periods separately. 
treatment group consists of individuals who have become separated since the last time they were observed. These individuals are kept in the sample as long as they remain separated ( $n=2,254$ for the survey years with political and gender variables).

For unemployment, we consider respondents in the main working-age range (25 to 64 years). The control group consists of working individuals who do not report unemployment. The treatment group ( $n=562$ for the survey years with political and gender variables) consists of individuals who transitioned from working to unemployment since the last time they were observed. They remain in the treatment group as long as they remained unemployed.

For health crises, we consider respondents in the main working-age range (25 to 64 years). The control group includes economically active individuals (working or unemployed). The treatment group consists of individuals who stopped working in the last 5 years and name health problems as the reason for not working $(n=479$ for the years that included political and gender variables), independently of whether they are currently working, unemployed or inactive.

\subsection{Measures}

\subsubsection{Dependent variable}

The dependent variable is vote intention for the SVP. Vote intention was determined by asking the (open) question, which party respondents would vote for if elections for the National Council were held tomorrow. Respondents who express a vote intention for the SVP are coded 1. Respondents who intend to vote for another party, have no vote intention, do not know their intention or vote for a candidate not for a party are coded as 0 . Respondents who refuse to answer the question are excluded from the analysis. Because our dependent variable groups together preferences for other parties with having no preference, our results do not distinguish between voters intending a shift from a different party to the SVP and newly mobilized voters for the SVP. However, the results remain the same if we exclude respondents without a party preference from the analysis.

\subsubsection{Independent variables}

The main independent variable of interest is the binary event variable indicating whether the event occurred (treatment group) or not (control group) as described in section 3.1. The same person may have experienced multiple events or the same event multiple times. In these cases, every occurrence is included in the treatment group.

We include also the main variables that should explain SVP support. Economic resources are measured by disposable household income, and missing values have been imputed. We include a linear variable referring to the income percentile of each year. ${ }^{4}$ We also include measures for political attitudes for both the economic (social

4 Our findings are consistent with various alternative income measures (absolute values, logarithm, income quintile, personal income and satisfaction with income). 
spending) and cultural dimensions (xenophobia). For the Confederation's social spending, we distinguish between individuals who are in favour of a diminution, individuals who are in favour of an increase and individuals who favour neither. For xenophobia, we distinguish between individuals who are in favour of Switzerland offering Swiss citizens better opportunities than foreigners, and individuals who selected one of the two other alternatives: in favour of equal opportunities or favouring neither category. Gender attitudes are measured by agreement to two statements on a scale of 0 to 10: "A pre-school child suffers if his or her mother works for pay" and "to have a job is the best guarantee for a woman as for a man to be independent". These commonly used items measure the attitude toward traditional gender roles legitimacy in society. The political explanation for populist radical right support is captured by questions on trust in the Federal Council (0-10).

\subsubsection{Control variables}

Using fixed-effects models, all time-invariant characteristics (e. g., cohort, education, gender) cannot bias the coefficients and are not part of the model. We include age and period effects as controls. Electoral campaigns have an effect on volatility (Kuhn 2016, $170 \mathrm{ff}$ ). The closer elections are, the more likely citizens are to change from no party preference to a preference for a party (activation effect) and the more likely they are to switch from one party to another (persuasion effect). Support for the SVP is significantly higher in the years of national elections (1999, 2003, 2007, $2011,2015)$ than in other years. We therefore measure period effects by including an indicator for election years.

Table 1 presents the descriptive statistics of all variables included in our models. We show descriptive statistics for Swiss citizens 18 years of age and above and survey years that include political variables. The analytical sample varies slightly between the events studied. The analysis on unemployment and health crisis cover only the main working years (25-64 years) and exclude inactive individuals (e.g. homemakers). The separation sample excludes individuals who have never lived with a partner during the panel study. The mean values of the variables therefore vary slightly between the different samples.

\subsection{Methods of analysis}

We first compare, for the three events separately, observations from individuals after they experienced the event with observations from before the event and from individuals who did not experience the event with respect to the likelihood of supporting the SVP. This cross-sectional approach serves as a reference before we test our hypotheses using a longitudinal approach.

We apply fixed-effects regression models to test our hypotheses. We use the linear probability model to estimate the fixed-effects models but check the robustness of our findings using nonlinear logistic regression. The main advantage of this longitudinal 
Table $1 \quad$ Descriptive statistics of the sample

\begin{tabular}{lrrrrr}
\hline & min & max & N & Mean & St. Dev \\
\hline SVP & 0 & 1 & 49258 & 0.121 & 0.326 \\
Separation & 0 & 1 & 49659 & 0.012 & 0.107 \\
Unemployment & 0 & 1 & 42809 & 0.013 & 0.114 \\
Health crisis & 0 & 1 & 42401 & 0.017 & 0.131 \\
Age & 18 & 97 & 49659 & 51.242 & 14.147 \\
Election year & 0 & 1 & 49659 & 0.238 & 0.426 \\
Lowest income quintile & 0 & 1 & 49629 & 0.140 & 0.347 \\
Less social expenses & 0 & 1 & 45974 & 0.220 & 0.414 \\
More social expenses & 0 & 1 & 45974 & 0.359 & 0.480 \\
Better chances for Swiss & 0 & 1 & 45974 & 0.300 & 0.458 \\
Job important for independence & 0 & 10 & 46057 & 8.171 & 2.331 \\
Children suffer with working mother & 0 & 10 & 45434 & 5.576 & 3.213 \\
Trust in Government & 0 & 10 & 45985 & 5.670 & 2.076 \\
\hline
\end{tabular}

Source: SHP $(2002-2009,2011,2014,2017)$. The descriptive statistics of the control variables are based on the separation sample.

approach is the identification of causal effects because we can rule out that selection into the event drives the results. In the first step, we ran a fixed-effects model for each event that controlled for age and election year, to test to what extent critical life events increase the probability of supporting the SVP. In the second step, we ran fixed-effects models that controlled for income, political and gender attitudes and political trust, to test whether changes in these variables had mediating effects. We use the same sub-sample for both analyses so that we can compare coefficients between models. If the regression coefficient of life events declines once the mediating variables are controlled in the model, we can conclude that these variables (income, attitudes and trust) are part of the mechanisms linking critical life events and populist votes. In the third step, we interact the life events with income and attitudes to test for cumulative effects. To avoid the arbitrary dichotomous distinction of results according to p-values, we focus on the effect size to interpret regression coefficients. We discuss effect sizes, direction of the effects and the plausibility of rejecting the zero-hypothesis for all effects whose p-values are lower than $0.1 .^{5}$

\section{Results}

We first look at vote intention for the SVP by event from a cross-sectional perspective. Table 2 compares observations from individuals who experienced the event with

$5 \quad$ When applying a p-value of $5 \%$, the significance of effects depends on small coding decisions. When focusing on effect sizes, such arbitrary choices do not affect the conclusions. 
observations from individuals who did not or have not yet experienced the event. The difference is only significant for separation. Separated individuals are less likely to support the SVP than partnered individuals, which is in line with results from previous cross-sectional studies. Unemployment and health crisis have no significant relationship with vote intention for the SVP. These results confirm that life events are not important factors to explain support for populist radical right parties from a cross-sectional perspective.

To test an intra-individual change in SVP preference, we look at the results of our fixed-effects models (Table 3). With models 1, 3 and 5, we test whether experiencing one of the events raises the propensity for right-wing party support. These models include only basic control variables (age and election year) that are clearly exog-

Table $2 \quad$ Cross sectional results: vote intention for the SVP by event

\begin{tabular}{lccccc}
\hline & & $\begin{array}{c}\text { no event/ } \\
\text { before event }\end{array}$ & after event & total & p-value \\
\hline Separation & $\%$ & 12.3 & 8.9 & 12.1 & 0.000 \\
Unemployment & $\mathrm{n}$ & 41,966 & 2,152 & 44,118 & \\
Health crisis & $\%$ & 11.4 & 10.2 & 11.4 & 0.166 \\
& $\mathrm{n}$ & 37,795 & 519 & 38,314 & \\
& $\mathrm{n}$ & 11.4 & 13.8 & 11.4 & 0.282 \\
\hline
\end{tabular}

Note: significance of the difference is tested by pooled logistic regression controlling for clustering within persons. Source: SHP (2002-2009, 2011, 2014, 2017)

enous to the event. We find that all three events increase support for the SVP by 2 to 3 percentage points. For the health crisis, although the coefficient is of similar magnitude, it reaches significance only at the $10 \%$ level.

These results do not show why we found such an effect. Therefore, we evaluate whether the main explanations for right-wing support mediate this effect. Models 2, 4 and 6 include political and gender attitudes, trust in government and income. In line with research on right-wing support, political attitudes are the most important predictor. Moreover, being in favour of fewer social expenses is as important as xenophobia. Gender values do not explain SVP support. Trust in government has a small effect on SVP preference. An income change does not seem to influence vote intention for the SVP. Contrary to our expectations, the coefficients of the event variables are unaffected by the inclusion of these supplementary variables. Hence, these events do not produce a drop in resources, changing issue opinion or a decrease in political trust that would explain why voters are more likely to support the SVP following a critical life event. 
Table 3

Fixed effects models predicting SVP preference following three life events (separation, unemployment, health crisis)

\begin{tabular}{|c|c|c|c|c|c|c|}
\hline & \multicolumn{2}{|c|}{ Separation } & \multicolumn{2}{|c|}{ Unemployment } & \multicolumn{2}{|c|}{ Health crisis } \\
\hline & M1 & $\mathrm{M} 2$ & M3 & M4 & M5 & M6 \\
\hline Event & $\begin{array}{l}0.025^{* * *} \\
(3.2)\end{array}$ & $\begin{array}{l}0.025^{* * *} \\
(3.2)\end{array}$ & $\begin{array}{l}0.027^{* *} \\
(2.4)\end{array}$ & $\begin{array}{l}0.028^{* *} \\
(2.5)\end{array}$ & $\begin{array}{l}0.026^{*} \\
(1.7)\end{array}$ & $\begin{array}{l}0.027^{*} \\
(1.7)\end{array}$ \\
\hline Lowest income quintile & & $\begin{array}{r}-0.000 \\
(-0.6)\end{array}$ & & $\begin{array}{l}-0.000 \\
(-0.9)\end{array}$ & & $\begin{array}{r}-0.000 \\
(-0.6)\end{array}$ \\
\hline $\begin{array}{l}\text { Less social expenses } \\
(5.9) \\
(5.3)\end{array}$ & & $0.021 * * *$ & & $0.021^{* * *}$ & & $\begin{array}{c}0.021 \text { *** } \\
(5.4)\end{array}$ \\
\hline More social expenses & & $\begin{array}{r}-0.003 \\
(-0.9)\end{array}$ & & $\begin{array}{c}-0.007^{\text {** }} \\
(-2.1)\end{array}$ & & $\begin{array}{c}-0.006^{*} \\
(-1.7)\end{array}$ \\
\hline Better chances for Swiss & & $\begin{array}{l}0.017^{* * *} \\
(4.9)\end{array}$ & & $\begin{array}{c}0.021^{* * *} \\
(5.5)\end{array}$ & & $\begin{array}{c}0.020^{* * *} \\
(5.3)\end{array}$ \\
\hline Job important for independence & & $\begin{array}{l}0.001^{*} \\
(1.7)\end{array}$ & & $\begin{array}{l}0.001 \\
(1.5)\end{array}$ & & $\begin{array}{l}0.001 \\
(1.4)\end{array}$ \\
\hline $\begin{array}{l}\text { Children suffer with working } \\
\text { mother }\end{array}$ & & $\begin{array}{l}0.001 \\
(1.0)\end{array}$ & & $\begin{array}{l}0.000 \\
(0.4)\end{array}$ & & $\begin{array}{l}0.000 \\
(0.3)\end{array}$ \\
\hline Trust in Government & & $\begin{array}{r}-0.001 \\
(-0.8)\end{array}$ & & $\begin{array}{c}-0.002^{\text {** }} \\
(-2.0)\end{array}$ & & $\begin{array}{c}-0.002^{*} \\
(-1.8)\end{array}$ \\
\hline Age & $\begin{array}{c}0.001^{* * *} \\
(3.1)\end{array}$ & $\begin{array}{l}0.001^{* *} \\
(2.3)\end{array}$ & $\begin{array}{c}0.001^{* * *} \\
(3.8)\end{array}$ & $\begin{array}{c}0.001^{* * *} \\
(3.0)\end{array}$ & $\begin{array}{l}0.001^{* * *} \\
(3.6)\end{array}$ & $\begin{array}{c}0.001^{* * *} \\
(2.7)\end{array}$ \\
\hline Election year & $\begin{array}{c}0.022^{* * *} \\
(9.6)\end{array}$ & $\begin{array}{c}0.022^{* * *} \\
(9.6)\end{array}$ & $\begin{array}{c}0.023^{* * *} \\
(9.4)\end{array}$ & $\begin{array}{c}0.023^{* * *} \\
(9.5)\end{array}$ & $\begin{array}{c}0.023^{* * *} \\
(9.5)\end{array}$ & $\begin{array}{c}0.023^{* * *} \\
(9.5)\end{array}$ \\
\hline Constant & $\begin{array}{c}0.070 * * * \\
(5.0)\end{array}$ & $\begin{array}{c}0.064^{* * *} \\
(4.2)\end{array}$ & $\begin{array}{c}0.055^{* * *} \\
(4.0)\end{array}$ & $\begin{array}{c}0.058^{* * *} \\
(3.9)\end{array}$ & $\begin{array}{c}0.058^{* * *} \\
(4.1)\end{array}$ & $\begin{array}{c}0.060 * * * \\
(3.9)\end{array}$ \\
\hline R-squared & 0.003 & 0.005 & 0.004 & 0.006 & 0.004 & 0.006 \\
\hline Number of persons & 10106 & 10106 & 9548 & 9548 & 9603 & 9603 \\
\hline Number of observations & 44098 & 44098 & 38294 & 38294 & 38256 & 38256 \\
\hline
\end{tabular}

${ }^{* * *} p<0.01,{ }^{* *} p<0.05,{ }^{*} p<0.10$; Source: SHP $(2002-2009,2011,2014,2017)$. T-statistics in parentheses.

The coefficients in models 2, 4 and 6 also allow us to interpret the size of the effect. Although an effect of 2 to 3 per cent seems modest, our model shows that the effect of the critical event is comparable to the effect of known explanations of populist radical right voting, such as xenophobia. Also, given that the overall probability to support the SVP amounts to only 12 per cent, an increase of 2 to 3 per cent is considerable. 
Table 4

Summary of fixed effects models predicting SVP support including interaction effects between event and income, attitudes, and political trust (separate model for each interaction)

\begin{tabular}{|c|c|c|c|c|c|c|}
\hline & \multicolumn{2}{|c|}{ Separation } & \multicolumn{2}{|c|}{ Unemployment } & \multicolumn{2}{|c|}{ Health crisis } \\
\hline & Coef. & t & Coef. & $t$ & Coef. & t \\
\hline Event & $0.034^{*}$ & $(1.7)$ & -0.036 & (1.3) & $.041^{* *}$ & (2.3) \\
\hline $\begin{array}{l}\text { Event* Income } \\
\text { percentile }\end{array}$ & -0.000 & $(-0.5)$ & $0.001 * *$ & (2.4) & -0.104 & $(-1.6)$ \\
\hline Event & $0.027^{* *}$ & $(2.3)$ & 0.011 & (0.6) & $0.047^{*}$ & $(1.8)$ \\
\hline Event * More social expenses & -0.004 & $(-0.2)$ & 0.032 & $(1.1)$ & -0.041 & $(-1.0)$ \\
\hline Event & $0.032^{* * *}$ & (3.5) & $0.032^{* *}$ & $(2.5)$ & 0.009 & (0.5) \\
\hline Event ${ }^{*}$ Less social expenses & -0.038 & (1.5) & -0.034 & $(-0.8)$ & 0.101 & (1.7) \\
\hline Event & $0.031 * * *$ & $(3.2)$ & $-0.039 * * *$ & $(2.7)$ & 0.008 & (0.4) \\
\hline Event ${ }^{*}$ Better chances for Swiss & -0.021 & $(1.0)$ & -0.040 & $(-1.3)$ & 0.055 & (1.3) \\
\hline Event & $0.133^{* * *}$ & $(3.7)$ & 0.047 & $(1.1)$ & 0.036 & (0.6) \\
\hline $\begin{array}{l}\text { Event }{ }^{*} J \text { ob important for } \\
\text { independence }\end{array}$ & $-0.013^{* * *}$ & $(-3.1)$ & -0.003 & $(-0.5)$ & -0.001 & (0.1) \\
\hline Event & -0.013 & $(-0.8)$ & 0.060 & $(2.2)$ & 0.002 & (0.1) \\
\hline $\begin{array}{l}\text { Event }{ }^{*} \text { Children suffer with } \\
\text { working mother }\end{array}$ & 0.007 & $(2.5)$ & -0.006 & $(-1.3)$ & 0.004 & (0.8) \\
\hline Event & 0.002 & $(0.1)$ & $0.058^{*}$ & $(1.8)$ & 0.037 & 0.87 \\
\hline Event* Trust in Government & 0.004 & (1.1) & -0.006 & $(-1.0)$ & -0.002 & $(-0.3)$ \\
\hline
\end{tabular}

${ }^{* * *} p<0.01,{ }^{* *} p<0.05,{ }^{*} p<0.10$; Source: SHP $(2002-2009,2011,2014,2017)$. T-statistics in parentheses.

We further interact the event variable with traditional explanations for right-wing support. We focus on the same variables (income, less social expenses, more social expenses, better chances for Swiss, job importance for independence, children suffering with a working mother and trust in government) as in the previous models. For the interaction, we take the mean value before the occurrence of the event. With seven interaction variables and three events, we estimated 21 separate models. Only three models show a significant interaction term. Figure 1 shows the significant interaction terms. The full models for these graphs are shown in Table 4.

Whereas we found no main effect of traditional gender values on SVP preference, we found four significant interactions that moderate the effect of negative life events on SVP support. Following separation, especially individuals with traditional 
Figure 1 Predicted probability to support SVP following negative events for different values of the gender variables and income levels
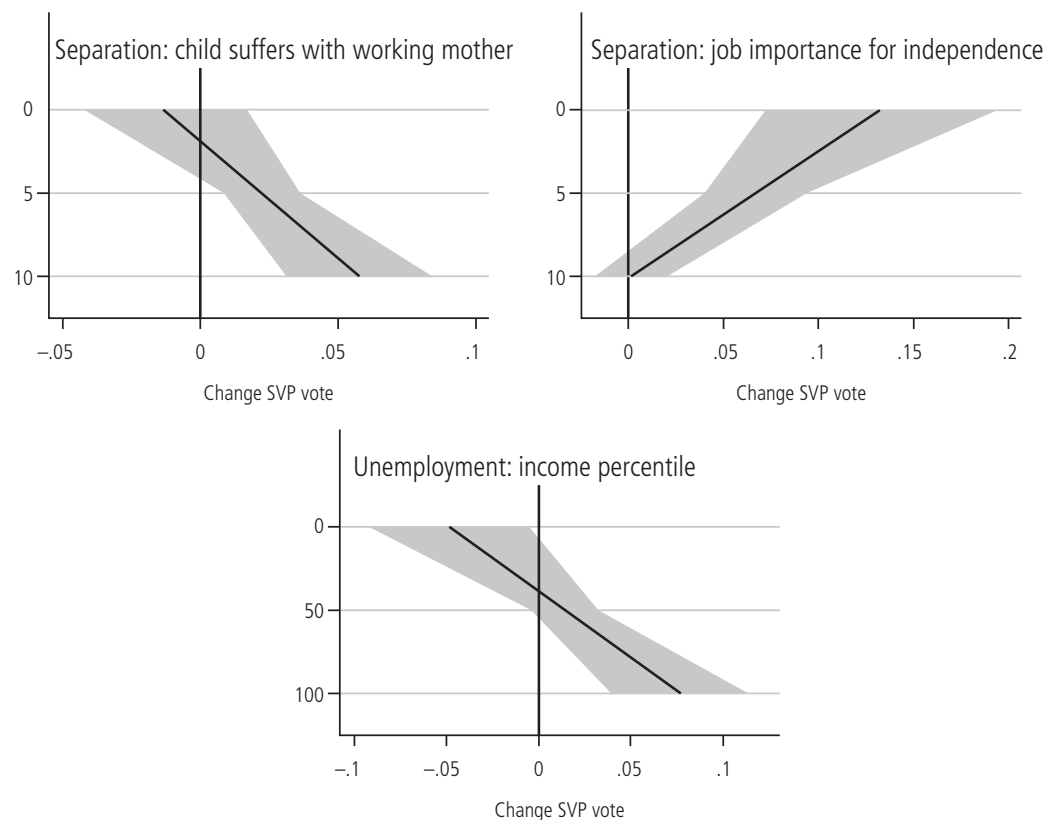

gender role values seem to switch to the SVP. Individuals who agree that pre-school children suffer with a working mother increase their SVP support after a separation. The same holds for individuals who disagree that a job is important for independence for a woman as for a man (see Figure 1). Thus, separation has the strongest effect on those who share the traditional family values of the SVP prior to the event. It is interesting that gender attitudes prior to the event matter, whereas main determinants of radical right voting such as anti-EU sentiments and xenophobic attitudes do not.

We also found a significant interaction between unemployment and income, although at a lower significance level. Individuals with higher income prior to unemployment are more likely to support the SVP following unemployment than individuals with lower income. This is contrary to our expectation that especially individuals with fewer financial resources would be more likely to prefer the SVP following a critical life event. Perhaps the financial consequences of unemployment are larger for individuals with a higher income, as they may experience a larger drop in income when they rely on unemployment benefits. Alternatively, the higher dependency of poorer individuals on financial support by the government could limit their support for the SVP in case of a job loss either due to unemployment or for health reasons. 


\section{Conclusion}

This study set out to assess the relationship between critical life events and populist radical right support. We examined the extent to which individuals experiencing relationship dissolution, unemployment or a health crisis change their party preference to the SVP and tested whether changes in attitudes, resources and political trust would explain changes in party preference. We found that the experience of all three critical life events increased the likelihood of supporting the SVP by 2 to 3 per cent. This shows that experiencing life course events has consequences for intended voting behaviour. On one side, this insight adds to our understanding of the sometimes far-reaching consequences of critical life course events, showing that they go beyond direct consequences for the individual involved, and reach the political domain, with potential consequences for society in terms of election outcomes. On the other side, it sheds light on potential drivers of volatility in political party preference and support for the populist radical right. People's party preference is not only determined by social class, the state of the economy or electoral campaigns (Bornschier and Kriesi 2012; Oesch 2008) but also by significant events that take place in citizens' personal lives. Moreover, we demonstrate that with respect to support for the SVP, in a fixed-effects model, the experience of these critical life events is as important as changes in well-known cultural determinants such as xenophobia.

Whereas our study showed that support for the SVP increases following relationship dissolution, unemployment or a health crisis, we were less successful in demonstrating why this happens. We explored conventional explanations for populist radical right support as potential drivers of the effect, expecting that life course events affect financial resources and may lead to more conservative attitudes, more extreme attitudes and a worse relation to politics. We found that although they were important for predicting a preference for the SVP, they did not explain why relationship dissolution and unemployment increase SVP support. Whereas studies have shown that critical events in the life course may change attitudes (Bardi et al. 2009), they are not necessarily affected in the same way for everyone. Randles and colleagues (2017) found that following life events, existing attitudes became more polarized. Moreover, the way in which life events affect attitudes may depend on the attitudes prior to the occurrence of the event, which paints a more complex picture than the hypothesized same direction of change for all. We found limited empirical support for this assertion. In most cases, the effect of critical life events on a preference for the SVP was not more pronounced for individuals who were closer aligned with the views of the SVP prior to the event. There were only two exceptions to this. Individuals with a higher income were more likely to prefer the SVP following unemployment, and individuals with more traditional gender attitudes were more likely to shift to the SVP following separation. It may be that 
the experience of separation make gender values more salient as they touch most directly on the private sphere.

The extent to which our findings are valid in another context than Switzerland remains to be explored. The Swiss context is particular not only with respect to the political landscape but also with respect to the consequences of these critical life events. For example, factors such as high divorce rates and low unemployment rates may affect how people experience these events. Also, social policies such as universal health care and generous unemployment benefits soften the negative consequences. It would be interesting to see to what extent our findings hold elsewhere.

More work is needed to shed light on the ways in which critical life events shape support for the SVP and change political attitudes and party preferences in general. When it comes to populist radical right support and support for any other political party, the considerations that lead to supporting a party are not only rational in nature but also have an emotional component (Hochschild, 2016). Critical life events may produce uncertainty in a person's life, they may also increase uncertainty about one's identity (Hogg, 2014). Insofar as a populist right wing party offers such a social identity, this may drive increased support following the experience of critical life events. Whereas our data did not allow us to test such a theory, the importance of a threatened identity for populist radical right support has received empirical support in the US context (Hochschild, 2016).

Our study had several limitations. The most notable one is the limited number of events occurring in the data as well as that the SVP is underrepresented in the SHP. It would be wise to expand this research to include other household panels as a way to augment the number of event occurrences to analyse, as well as to see to what extent our findings are valid in contexts outside of Switzerland. Also, we measured vote intentions, but this may not translate directly into actual voting behaviour. Finally, our analysis relies on the assumption that selection into life events is not driven by changing party support or attitudes. Generally, we do not think this assumption is very problematic as it is unlikely that political views influence health, unemployment or separation. Overcoming these limitations, we encourage future studies to further explore the consequences of what happens in individual life courses for political and other societal outcomes.

\section{References}

Aarts, Kees, and Jacques Thomassen. 2008. Dutch Voters and the Changing Party Space 1989-2006. Acta politica 42(2/3): 203-234.

Ackermann, Kathrin, Eros Zampieri, and Markus Freitag. 2018. Personality and Voting for a RightWing Populist Party - Evidence from Switzerland. Swiss Political Science Review 24(4): 545-564.

Amengay, Abdelkarim, and Daniel Stockemer. 2018. The Radical Right in Western Europe: A MetaAnalysis of Structural Factors. Political Studies Review 17(1): 30-40. 
Andersen, Robert, and Josh Curtis. 2015. Social Class, Economic Inequality, and the Convergence of Policy Preferences: Evidence from 24 Modern Democracies. Canadian Review of Sociology/Revue canadienne de sociologie 52: 266-288.

Arzheimer, Kai. 2011. Electoral Sociology - Who Votes for the Extreme Right and Why - and When? Pp. 35-50 in The Extreme Right in Europe: Current Trends and Perspectives edited by Uwe Backes and Patrick Moreau. Göttingen: Vandenhoeck \& Ruprecht.

Arzheimer, Kai. 2018. Explaining electoral support for the radical right. Pp. 143-165 in The Oxford Handbook of the Radical Right edited by Jens Rydgren. New York, NY: Oxford University Press.

Bardi, Anat, Julie Anne Lee, Nadi Hofmann-Towfigh, and Geoffrey Soutar. 2009. The Structure of Intraindividual Value Change. Journal of Personality and Social Psychology 97(5): 913-929.

Batavia, Andrew I., and Richard L. Beaulaurier. 2001. The Financial Vulnerability of People with Disabilities: Assessing Poverty Risks. Journal of Sociology and Social Welfare 28(1): 139-162.

Bernhard, Laurent. 2017. Three Faces of Populism in Current Switzerland: Comparing the Populist Communication of the Swiss People's Party, the Ticino League, and the Geneva Citizens' Movement. Swiss Political Science Review 23(4): 509-525.

Betz, Hand-Georg. 1994. Radical Right-Wing Populism in Western Europe. London: Macmillan.

Betz, Hans-Georg. 2005. Against the System: Radical Right-Wing Populism's Challenge to Liberal Democracy. Pp 25-40 in Movements of Exclusion: Radical Right-Wing Populism in the Western world, edited by Jens Rydgren. Hauppage, New-York: Nova Science Publishers.

Billiet, Jaak, and Hans de Witte. 1995. Attitudinal Dispositions to Vote for a 'New' Extreme RightWing Party: The Case of 'Vlaams Blok'. European Journal of Political Research 27(2): 181-202.

Bjørklund, Tor. 2007. Unemployment and the Radical Right in Scandinavia: Beneficial or Non-Beneficial for Electoral Support? Comparative European Politics 5(3): 245-263.

Bornschier, Simon, and Hanspeter Kriesi. 2012. The Populist Right, the Working Class, and the Changing Face of Class Politics. Abingdon and New York: Routledge.

Brand, Jennie E. 2015. The Far-Reaching Impact of Job Loss and Unemployment. Annual Review of Sociology 41(1): 359-375.

Chapman, Jenny. 1985. Marital Status, Sex and the Formation of Political Attitudes in Adult Life. Political Studies 33(4): 592-609.

Corbetta, Piergiorgio, and Pasquale Colloca. 2013. Job Precariousness and Political Orientations: The Case of Italy. South European Society and Politics 18(3): 333-354.

Cramer, Katherine J. 2016. The Politics of Resentment. Rural Consciousness in Wisconsin and the Rise of Scott Walker. Chicago: The University of Chicago Press.

Dalton, Russel J., and Steven A. Weldon. 2005. Public Images of Political Parties: A Necessary Evil? West European Politics 28(5): 931-951.

Dassonneville, Ruth. 2012. Electoral Volatility, Political Sophistication, Trust and Efficacy: A Study on Changes in Voter Preferences During the Belgian Regional Elections of 2009. Acta Politica 47(1): $18-41$.

Duina, Francesco, and Dylan Carson. 2019. Not So Right After All? Making Sense of the Progressive Rhetoric of Europe's Far-Right Parties. International Sociology 35(1): 3-21.

Fahs, Breanne. 2007. Second Shifts and Political Awakenings. Journal of Divorce \& Remarriage 47(3/4): 43-66.

Geishecker, Ingo, and Thomas Siedler. 2011. Job Loss Fears and (Extreme) Party Identification: First Evidence From Panel Data. CEGE Discussion Papers 129. Göttingen: Georg-August-Universität Göttingen.

Hatemi, Peter K. 2013. The Influence of Major Life Events on Economic Attitudes in World of Gene-Environment Interplay. American Journal of Political Science 57(4): 987-1007. 
Heine, Steven J., Travis Proulx, and Kathleen D. Vohs. 2006. The Meaning Maintenance Model: On the Coherence of Social Motivations. Personality and Social Psychology Review 10(2): 88-110.

Hochschild, Arlie R. 2016. Strangers in Their Own Land: Anger and Mourning on the American Right. New York: The New Press.

Hogg, Michael A. 2014. From Uncertainty to Extremism: Social Categorization and Identity Processes. Current Directions in Psychological Science, 23(5): 338-342.

Hooghe, Marc, Sofie Marien, and Teun Pauwels. 2011. Where Do Distrusting Voters Turn if There is No Viable Exist or Voice Option? The Impact of Political Trust on Electoral Behaviour in the Belgian Regional Elections of June 2009. Government and Opposition 46(2): 245-273.

Janoff-Bulman, Ronnie. 1999. Rebuilding Shattered Assumptions After Traumatic Life Events: Coping Processes and Outcomes. Pp. 305-323 in Coping: The Psychology of What Works, edited by C.R. Snyer. Oxford: Oxford University Press.

Kitschelt, Herbert, and Anthony J. McGann. 1995. The Radical Right in Western Europe: A Comparative Analysis. Ann Arbor: University of Michigan Press.

Kern, Holger L. 2010. The Political Consequences of Transitions Out Of Marriage in Great Britain. Electoral Studies 29(2): 249-258.

Kohler, Ulrich. 2002. Changing Class Locations and Partisanship in Germany. Pp. 117-31 in The Social Logic of Politics. Personal Networks as Contexts for Political Behavior, edited by Alan S. Zuckerman. Philadelphia: Temple University Press.

Kuhn, Ursina. 2009. Stability and Change in Party Preferences. Swiss Political Science Review 15 (3): 463-494.

Kuhn, Ursina. 2016. Dynamics of Party Preferences: A Study on the Volatility and Stability of Individuals Using Household Panel Data from Germany, Great Britain and Switzerland. University of Zurich. http://opac.nebis.ch/ediss/20162715.pdf.

Lubbers, Marcel and Marcel Coenders. 2017. National Attitudes and Voting for the Radical Right in Europe. European Union Politics 18(1): 98-118.

Luhmann, Maike, Wilhelm Hofmann, Michael Eid, and Richard E. Lucas. 2012. Subjective Well-Being and Adaptation to Life Events: A Meta-Analysis on Differences Between Cognitive and Affective Well-Being. Journal of Personality and Social Psychology 102(3): 592-615.

McGann, Anthony J., and Herbert Kitschelt. 2005. The Radical Right in the Alps: Evolution of Support for the Swiss SVP and Austrian FPÖ. Party Politics 11(2): 147-171.

Mudde, Cas. 2007. Populist Radical Right Parties in Europe. Cambridge: Cambridge University Press.

Nicolet, Sarah, and Pascal Sciarini. 2006. When Do Issue Opinions Matter, and to Whom? The Determinants of Long-Term Stability and Change in Party Choice in the 2003 Swiss Elections. Swiss Political Science Review 12(4): 159-90.

Oesch, Daniel. 2008. Explaining Workers' Support for Right-Wing Populist Parties in Western Europe: Evidence from Austria, Belgium, France, Norway, and Switzerland. International Political Science Review 29(3): 349-373.

Plutzer, Eric. 2002. Becoming a Habitual Voter: Inertia, Resources, and Growth in Young Adulthood. American Political Science Review 96(1): 41-56.

Prior, Markus. 2010. You've Either Got It or You Don't? The Stability of Interest Over the Life Cycle. Journal of Politics 72(3): 747-766.

Randles, Daniel, Steven J. Heine, Michael Poulin, and Roxane Cohen Silver. 2017. Experienced Adversity in Life is Associated with Polarized and Affirmed Political Attitudes. Social Psychology and Personality Science 8(6): 652-659.

Rink, Nathalie, Karen Phalet, and Marc Swyngedouw. 2008. The Effects of Immigrant Population Size, Unemployment, and Individual Characteristics on Voting for the Vlaams Blok in Flanders 1991-1999. European Sociological Review 25(4): 411-424. 
Rydgren, Jens. 2007. The Sociology of the Radical Right. Annual Review of Sociology 33: 241-262.

Sanders, David, and Malcolm Brynin. 1999. The Dynamics of Party Preference Change in Britain, 1991-1996. Political Studies 47: 219-239.

Salmela, Mikko, and Christian Von Scheve. 2017. Emotional Roots of Right-Wing Political Populism. Social Science Information 56(4): 567-595.

Schmitt-Beck, Rüdiger, Stefan Weick, and Bernhard Christoph. 2006. Shaky Attachments: Individual-Level Stability and Change of Partisanship among West German Voters, 1984-2001. European Journal of Political Research 45: 581-608.

Schofield, Deborah J., Richard Percival, Megan E. Passey, Rupendra N. Shrestha, Emily J. Callander, and Simon J. Kelly. 2010. The Financial Vulnerability of Individuals with Diabetes. The British Journal of Diabetes \& Vascular Disease 10(6): 300-304.

Schraff, Dominik. 2019. Politically Alienated Through Low-Wage Work? Evidence from Panel Data. Swiss Political Science Review 25(1): 19-39.

Schur, Lisa, and Meera Adya. 2013. Sidelined or Mainstreamed? Political Participation and Attitudes of People with Disabilities in the United States. Social Science Quarterly 94(3): 811-839.

Smith, Tom W. 2007. Changes in Family Structure, Family Values, and Politics, 1972-2006. GSS Social Change Report 53. Chicago, IL: National Opinion Research Center, University of Chicago.

Van der Meer, Tom W., Erika van Elsas, Rozemarijn Lubbe, and Wouter van der Brug. 2015. Are Volatile Voters Erratic, Whimsical or Seriously Picky? A Panel Study of 58 Waves into the Nature of Electoral Volatility (The Netherlands 2006-2010). Party Politics 21(1): 100-114.

Vaus, David, Matthew Gray, Lixia Qu, and David Stanton. 2017. The Economic Consequences of Divorce in Six OECD Countries. Australian Journal of Social Issues 52(2): 180-199.

Voorpostel, Marieke, and Hilde Coffé. 2012. Transitions in partnership and parental status, gender, and political and civic participation. European Sociological Review 28(1): 28-42.

Voorpostel, Marieke, Hilde Coffe, and Ursina Kuhn. 2018. The Link between Separation and Political Party Preference: Selectivity or Causal Influence? Journal of Elections, Public Opinion and Parties.

Wilson, J.Matthew, and Michael Lusztig. 2004. The Spouse in the House: What Explains the Marriage Gap in Canada? Canadian Journal of Political Science/Revue Canadienne de Science Politique 37(4): 979-995. 